This synopsis is based on a student thesis entitled 'De optimalisatie van een wegennet in beboste gebieden - een nieuw model voor zowel vlak als geaccidenteerd terrein' by M. P. Reinders \& P. J. M. Wijngaard, Department of Forest Technique and Forest Products, Agricultural University, Wageningen, 1984. vi +161 pp., 32 figs., 29 refs., appendices. Dutch, English summary.

Available as paper copy (order R033P, $f 30$ including postage) or on microfiche (order R033M, f 17,50 including postage) at: NARD, clo Pudoc, P.O. Box 4, 6700 AA Wageningen, Netherlands (telex 45015 blhwg $\mathrm{nl}$ ).

\title{
Growth and morphogenesis of shoot initials of Douglas fir, Pseudotsuga menziesii (Mirb.) Franco, in vitro
}

P. W. Evers (Dorschkamp Research Institute for Forestry and Landscape Planning, P.O.Box 23, 6700 AA Wageningen, Netherlands)

Received 6 May 1985; accepted 20 May 1985

Abstract. An optimalized method of micropropagation of Douglas fir is described. Seasonal changes were found in optima for nitrate and sucrose in the medium and in the optimum for the light intensity during the culture of shoot initials. Differences in morphogenesis were obtained from shoot initials that had been isolated from buds in 10 topophysical positions on 2-year-old trees. These differences between the shoots were influenced by the medium, the light intensity, and by forcing or topping the mother trees or treating them with growth regulators. Shoots from each of the topophysical positions had a characteristic photosynthesis.

Key words: topophysis, season, photosynthesis, micropropagation

Introduction. In trees showing a basic growth programme, architecture can be used to pin-point physiological gradients. The effect of these gradients is commonly referred to as topophysis. Both architecture and topophysis are thus closely related to basic principles such as physiological ageing (Romberger, 1976); it is therefore obvious that these properties of the tree will often determine the success of vegetative propagation. Thus the growth and differentiation of a tree species have to be studied before methods of vegetative propagation can be developed (Durzan, 1982). Using the technique of micropropagation offered the opportunity of studying morphogenesis of parts of the tree and the consequences of tree physiology in a controlled environment (Campbell \& Durzan, 1976). In the in vitro system, the morphogenesis of tree meristem products can be studied and thus the consequences of 
endogenous physiological gradients of the tree can be ascertained (Borchert, 1976); furthermore, in the in vitro situation fluctuating gradients are stabilized.

It is difficult to draw conclusions about the in vivo situation in the tree from the in vitro experiments: not only is there genetic variation, but explants are taken during the 'flow' of gradients in the transition from one architectural phase to the next, a transition which, moreover, is modified by environmental factors. It is apparent that the point of time during the development of the tree at wich the tissues are isolated is crucial for the later behaviour of the tissues in vitro. Also, if the architectural phase is artificially changed, reaction patterns and physiological gradients of the tree can be studied.

Douglas fir (Pseudotsuga menziesii (Mirb.) Franco) was chosen to study the morphogenesis of shoot initials in vitro for three main reasons: because it has a wellknown architectural model, Massart's model (Edelin, 1977); because it was thought that tissue culture could overcome problems in classic vegetative propagation; and because the in vitro system enables endogenous physiological gradients in a gymnosperm species to be studied simultaneously.

Materials and methods. Buds were isolated from forced 2-years-old Douglas fir trees, sterilized and cultured on Heller media. Optimum concentrations of medium components and optimum pre-treatments of mother trees were determined for the development of buds from 10 topophysical positions.

Results. The influence of the $\mathrm{NaNO}_{3}$ concentration, the light intensity and the sucrose concentration on the growth and morphogenesis of shoot initials excised from vegetative buds of 2-year-old Douglas fir trees was studied in vitro.

The mean optimum $\mathrm{NaNO}_{3}$ concentration for the extension growth in vitro of shoot initials increased from $10.8 \mathrm{mmol} / \mathrm{l}$ in January to $15.3 \mathrm{mmol} / 1$ in April. The optimum light intensity for quantitative morphogenesis of the shoots increased from $36.4 \mathrm{~W} \mathrm{~m}^{-2}$ in January to a value above $43 \mathrm{~W} \mathrm{~m}^{-2}$ in March followed by a decrease to $24.5 \mathrm{~W} \mathrm{~m}^{-2}$ in April. The optimum sucrose concentration for maximal absolute increase in length of the shoots decreased from $37.5 \mathrm{~g} / \mathrm{l}$ in January to $33 \mathrm{~g} / \mathrm{l}$ in April.

The shoots were isolated from buds in 10 topophysical positions. Shoot initials from axillary buds are smaller than those isolated from terminal buds. In some positions the optima for growth and development did not coincide with the mean optima for all positions.

A high sucrose concentration in the medium generally inhibited the maximum net photosynthesis $\left(P_{\mathrm{Nm}}\right)$ and the photochemical efficiency $\left(\alpha_{\mathrm{n}}\right)$ of shoots cultured in vitro; it also resulted in a higher compensation irradiance $\left(I_{\mathrm{c}}\right)$ except when the initials of these shoots had originally been isolated from buds on the stem. Shoots grown at a high light intensity $\left(43 \mathrm{~W} \mathrm{~m}^{-2}\right)$ demonstrated a lower dark respiration $\left(R_{\mathrm{d}}\right)$ and $P_{\mathrm{Nm}}$ compared with shoots grown at a low light intensity $\left(22 \mathrm{~W} \mathrm{~m}^{-2}\right)$.

Shoots from all topophysical positions had their own characteristic parameters of photosynthesis; this was especially clear when the shoots were cultured at a low light intensity. Indications were found that in general shoots originating from buds in the least exposed places in the trees had a higher $P_{\mathrm{Nm}}$ and $\alpha_{\mathrm{n}}$ and a lower $I_{\mathrm{c}}$, which 
could be correlated with their high relative growth rates.

The optimum light intensity and sucrose concentration for growth and morphogenesis in vitro of shoot initials were $22 \mathrm{~W} \mathrm{~m}^{-2}$ and $15 \mathrm{~g} / \mathrm{l}$, respectively. A lower light intensity and a higher sucrose concentration reduced extension growth, diameter growth and needle development. Lowering the light intensity could not be compensated by a higher sucrose concentration. However, shoots from the lowest buds on the stem grew faster on a medium containing $45 \mathrm{~g} / \mathrm{l}$ sucrose than on a medium with $15 \mathrm{~g} / \mathrm{l}$ sucrose. Topping the trees only stimulated growth of the shoots at a low light intensity $\left(8 \mathrm{~W} \mathrm{~m}^{-2}\right)$ when compared with shoots from untopped trees; the development of the needles was not influenced. In shoots from buds on the lower stem part of the second flush of the second year, all the primordia developed into needles but in those from other buds only some of the primordia developed into needles; the lowest number of needles were produced on shoots that originated from the highest bud positions. After the trees were topped the apical meristem extension of shoots from terminal buds was stimulated.

BAP in the medium strongly inhibited the growth of shoots from untreated trees. It stimulated organogenesis on $8.4 \%$ of these explants. Applying $\mathrm{GA}_{3}$ to the tree followed by IAA in vitro stimulated the growth of shoots from the terminal buds of the tree and of the highest branches, but inhibited the growth of shoots from axillary buds near these positions. Applying IAA to the tree but not to the medium stimulated the growth of shoots from buds on the middle branches. When $\mathrm{GA}_{3}$ and IAA had been applied to the tree and IAA to the medium the growth of shoots from the terminal buds on the lowest branches was stimulated but the growth of shoots from axillary buds near this position was inhibited.

In conclusion differences in morphogenesis of the buds in different topophysical positions are influenced by the medium, the light intensity, by forcing or topping of the mother tree and by treating them with growth regulators.

Acknowledgement. This research was a joint project of 'Dorschkamp' and the Departments of Silviculture and Horticulture of the Agricultural University of Wageningen.

\section{References}

Borchert, R., 1976. The concept of juvenility in woody plants. Acta Horticulturae 56: 21-36.

Campbell, R. A. \& D. J. Durzan, 1976. Vegetative propagation of Picea glauca by tissue culture. $\mathrm{Ca}$ nadian Forest Research 6: 240-243.

Durzan, D. J., 1982. Cell and tissue culture in forest industry. In: J. M. Bonga \& D. J. Durzan (Eds.), Tissue culture in forestry. Martinus Nijhof, The Hague, pp. 36-71.

Edelin, C., 1977. Images de l'architecture des conifères. Thèse biologie végétale, Academie de Montpellier, 225 pp.

Romberger, J. A., 1976. An appraisal of prospects for research on juvenility in woody perennials. Acta Horticulturae 56: 301-317.

This synopsis is based on a doctoral thesis, Agricultural University, Wageningen, 1984. 265 pp., 58 figs., 46 tables, 178 refs., 2 appendices. English, Dutch summary. 
Available as paper copy (order R035P, $f 40$ including postage) or on microfiches (order R035M, $f 22,50$ including postage) at: NARD, clo Pudoc, P.O. Box 4, 6700 $A A$ Wageningen, Netherlands (telex $45015 \mathrm{blhwg} \mathrm{nl).}$ 